\title{
A encruzilhada entre rua e internet: redes sociais como fator de mobilização nas manifestações brasileiras em 2013
}

Mirian Aparecida Meliani Nunes

\section{MALINI, F.; ANTOUN, $\mathrm{H}$.}

A internet e a rua: ciberativismo e

mobilização nas redes sociais.

Porto Alegre: Sulina, 2013, 278p.

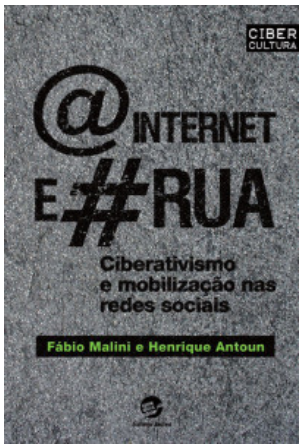

Resumo: Pesquisadores e ativistas, Fábio Malini e Henrique Antoun escreveram sob o calor das manifestações que tomaram as ruas das maiores cidades brasileiras, em junho de 2013. Lançaram seu livro em agosto, apenas dois meses depois do auge do movimento, um feito que estabelece, ao mesmo tempo, a força e os limites da obra. Os autores iniciam sua narrativa com a história do ciberespaço e da cibercultura, e demonstram como o encontro entre ruas e redes digitais transforma-se em um fenômeno capaz de mobilizar e traçar novas rotas de atuação política.

Palavras-chave: ciberativismo e cibercultura; midialivrismo; manifestações de junho de 2013; redes sociais.

Abstract: The crossroads between the streets and the internet: social networks as a mobilizing factor for the Brazilian demonstrations in 2013 - Fabio Malini and Henrique Antoun are researchers and political activists. They wrote a book under the heat of the manifestations that 
took the streets of major Brazilian cities, in June 2013. They released their book in August, only two months after the heyday of the movement, reaching a speed that set, at the same time, the strength and limits of the work. They begin their narrative summarizing the history of cyberspace and cyberculture, and discover a meeting place between the streets and digital networks, a phenomenon capable of mobilizing and drawing new routes for political action.

Keywords: cyberactivism; cyberculture; free media activism: June 2013 manifestations; social networks.

Lançar-se ao campo de batalha para conquistar mentes e corações faz parte da rotina dos ativistas das redes digitais. Essa parece ser a grande motivação do ágil lançamento do livro A internet e a rua: ciberativismo e mobilização nas redes sociais, ainda em meio à perplexidade que tomou conta do país durante e pouco após as manifestações de Junho de 2013 nas maiores cidades brasileiras. Se, naquele momento, tal rapidez foi vista como o aspecto positivo da obra, hoje se apresenta também como um campo limitador do alcance da análise empreendida pelos autores.

A partir da constatação de que as grandes corporações digitais Facebook e Twitter ofereceram o suporte ideal para a organização de manifestantes em diferentes eclosões rebeldes espalhadas pelo mundo, os autores iniciam a obra traçando um histórico da comunicação no ciberespaço, passam pela construção da ideia de cibercultura e chegam ao estabelecimento do ciberativismo como realidade em diferentes plataformas digitais, desde as pioneiras ferramentas de discussão da Usenet e BBSs (p. 19) até o advento da web 2.0. De maneira engajada, defendem o uso político de todas as frentes digitais, a fim de empreender uma "guerrilha de narrativas", tal como propõe Ivana Bentes, logo no prefácio da obra.

Ao descreverem o modus operandi da web 1.0, os autores chamam a atenção para a forma como foi estabelecido o propósito momentâneo de centralizar a informação na internet - originalmente caótica, no sentido de permitir dinâmicas comunicacionais em sistema de rede, ou seja, múltiplas, policêntricas e não-hierárquicas (DELEUZE e GUATTARI, 1980, p. 42). Para Malini e Antoun, a estratégia incluiu a construção de grandes portais, mantidos por corporações globais, que trataram de acumular e distribuir conteúdos de todos os tipos, geralmente organizados a partir de um eixo fixo, que se convencionou nomear como homepage. Uma observação interessante é que esses grupos, ancorados na visão linear da realidade, utilizaram a metáfora do espaço virtual como representação de espaços físicos conhecidos, sempre com uma porta de entrada para "visitantes", na tentativa de ordenar a experiência digital. O caminho dessa visita seria, portanto, controlado pelo anfitrião (a corporação proprietária da página), que se esforçava por arrumar os cômodos da casa, de modo a agradar os sentidos e não gerar desconforto ou surpresa.

Com a chegada da Web 2.0, a lógica do acúmulo de conteúdos centralizados nos portais e em suas homepages é substituída pela nova organização das redes sociais, especialmente Facebook e Twitter, basedas em perfis e timelines. Não há mais distinção, 
segundo os autores, entre consumo e produção da informação. A palavra de ordem é colaboração e há a confecção de murais de notícias em sistema colaborativo com os amigos, configurando comunidades em que todos são autores.

É sintomático dessa nova configuração que as empresas mais valorizadas são exatamente aquelas que não produzem qualquer tipo de conteúdo, oferecendo apenas o suporte para a produção coletiva. É justamente sob essa perspectiva que surge a oportunidade para a organização em larga escala das demandas de grupos de ativistas. Eles agendam ações que começam nas redes e se estendem para as ruas ou vice-versa, atingindo públicos variados. Mais do que isso, os autores chamam a atenção para a simultaneidade desse encontro. É possível estar nas ruas e nas redes ao mesmo tempo, ocupando espaços que não são excludentes, mas complementares e simultâneos. Esse é o eixo central do livro e sua maior contribuição para o debate em torno do ciberativismo.

Por outro lado, nos capítulos iniciais, ao descreverem as lutas antidisciplinares empreendidas principalmente nas décadas de 60 e 70, em que grupos rebeldes se insurgem contra o que resta da sociedade disciplinar - tal como preconizada por Foucault (1985) -, os autores, algumas vezes, fazem afirmações que parecem saltar etapas, do ponto de vista histórico. Talvez falte rigor metodológico ao atribuir, por exemplo, a revogação da lei inglesa que punia a homossexualidade, na década de 60, simplesmente, ao visual andrógino adotado pelos Beatles e seguido por grande parte da juventude (p. 28). Outro momento em que o leitor pode se surpreender com a análise dos autores é quando eles atribuem uma suposta "desistência" da União Soviética de continuar com o comunismo ao receio do uso militar da internet no projeto norte-americano de Guerra nas Estrelas, uma vez que a antiga potência seria incapaz de responder com algo à altura (p. 32).

Ainda assim, ao deter-se nos aspectos específicos da cultura hacker, do ciberativismo e do midialivrismo, especialmente no método de análise de gráficos gerados por algoritmos, a obra retoma o rigor e alcança o propósito da narrativa pulsante que os autores ambicionam. Os mapas, desenhados por aplicativos, fornecem vasto material de análise dos nós e dos desdobramentos dessa cartografia das controvérsias, cujo embate faz parte da rotina das redes sociais digitais. A utilidade metodológica fica demonstrada no estudo da mobilização digital do Movimento \#15M, relativo à ocupação das ruas espanholas pelos Indignados, em 15 de maio de 2011. O caso brasileiro, das Manifestações de Junho de 2013, ocupa as páginas finais do livro, com a descrição dos resultados obtidos pelo mesmo tipo de análise. Sem dúvida, para quem deseja atuar com métodos quantitativos de análise das redes sociais, as ferramentas utilizadas pelos autores fornecem dados importantes sobre os modos de disseminação de discursos e narrativas em ambientes digitais. Cabe estabelecer as bases e as perguntas relevantes para a investigação que se pretende desenvolver. 
Mirian Aparecida Meliani Nunes é jornalista, mestre em Comunicação e Semiótica pela PUC-SP e membro do Grupo de Pesquisa em Comunicação e Criação nas Mídias do PEPGCOS-PUC/SP.

mimeliani@gmail.com

\section{Referências}

DELEUZE, Guilles; GUATTARI, Felix. Mil platôs: capitalismo e esquizofrenia 2 (volume I). Les Editions de. Minuit, Paris, 1980. São Paulo, SP: Editora 34, 1995.

FOUCAULT, Michel. História da Sexualidade III. O cuidado de si. Trad. Maria Thereza da Costa Albuquerque, revisão técnica de José Augusto Guilhon Albuquerque. Rio de Janeiro: Ediç̧̃es Graal, 1985. 